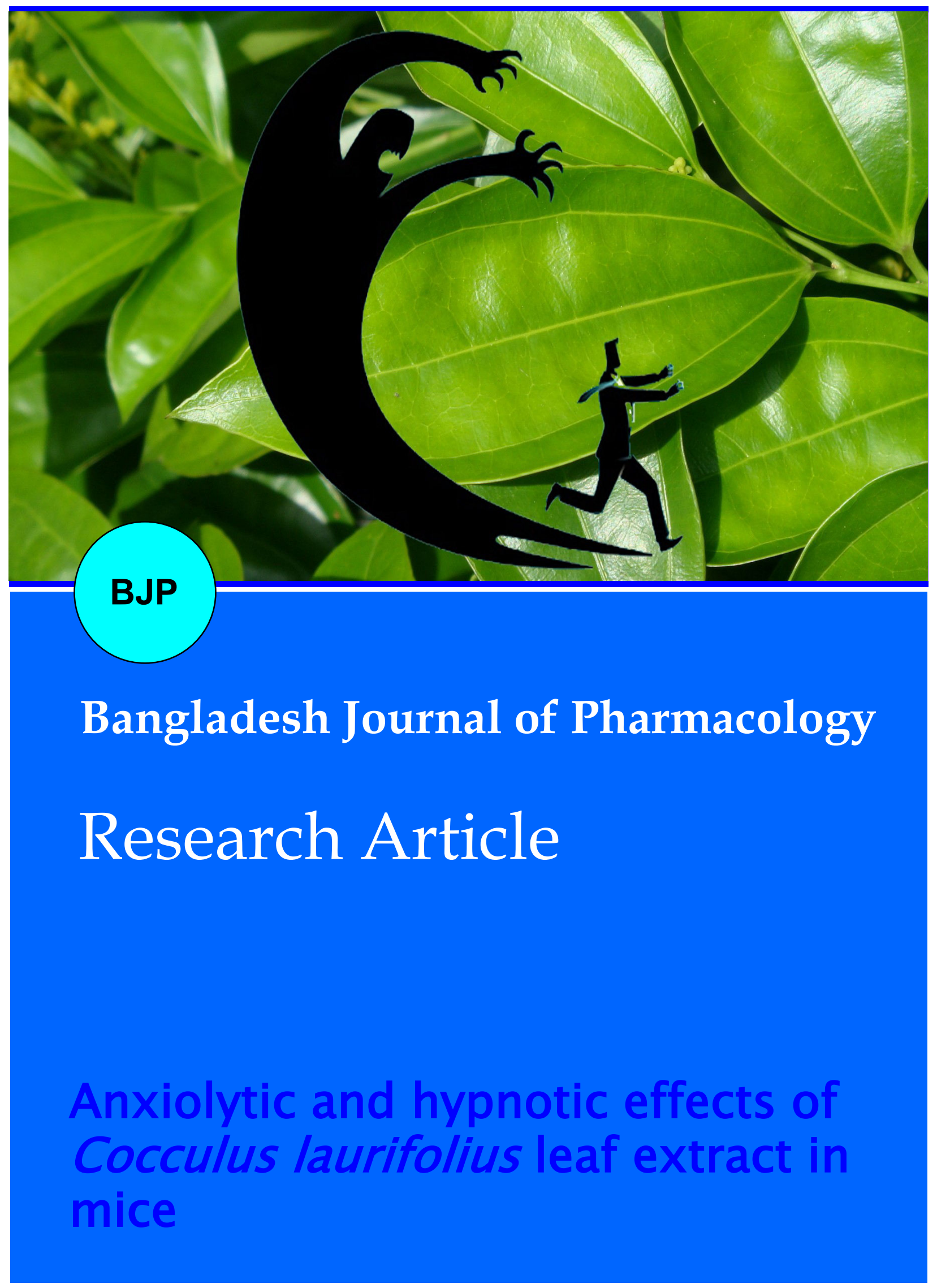




\title{
Anxiolytic and hypnotic effects of Cocculus laurifolius leaf extract in mice
}

\author{
Sidra Maqbool and Ishrat Younus \\ Department of Pharmacology, Faculty of Pharmacy, Hamdard University, Madinat al-Hikmah, Muhammad Bin \\ Qasim Avenue, Karachi, Pakistan.
}

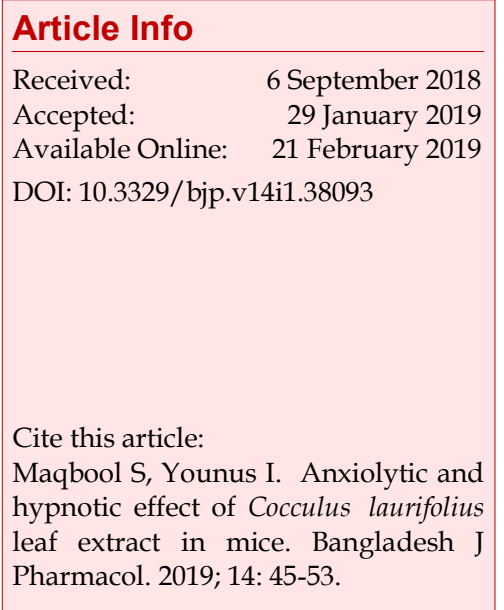

\begin{abstract}
The present study aims to assess the anxiolytic and hypnotic activity of ethanolic extract of Cocculus laurifolius leaf in mice. Anxiolytic activity was observed using behavioral paradigms while hypnotic activity was assessed by sodium pentobarbital induced hypnosis in mice. Animals were treated with the extract at dose 200 and $400 \mathrm{mg} / \mathrm{kg}$ orally for 30 days. Anxiolytic and hypnotic effect were observed on day 1, 7, 15 and 30 of treatment. Significant increase in the number of entries and time spent in open arm were observed in elevated plus maze. Similar results were observed in light/dark, open field and hole board test. The anxiolytic effect was substantially greater at dose 200 $\mathrm{mg} / \mathrm{kg}$ in comparison to dose $400 \mathrm{mg} / \mathrm{kg}$. Minimal hypnotic activity was observed with decrease in onset and prolongation in duration of sleep at dose $400 \mathrm{mg} / \mathrm{kg}$, while dose $200 \mathrm{mg} / \mathrm{kg}$ did not produce any hypnotic effect. These results showed that the ethanolic extract of $C$. laurifolius leaf might have potential anxiolytic and hypnotic activity in mice.
\end{abstract}

\section{Introduction}

Approximately 450 million of the world population suffers from the mental and behavioral disorders, and according to $\mathrm{WHO}$ health report this ratio will increase up to $15 \%$ by 2020 (Reynolds, 2003). Globally most common mental disorders included anxiety and insomnia.

Anxiety is the most common psychiatric illness characterized by feeling of anxiousness, fear, apprehension and nervousness, accompanied with symptoms of sympathetic activity like elevated pulse rate, decrease in salivation and augmented muscle activity. Gamma aminobutyric acid (GABA) system is the widely accepted mediator that plays a central role in the pathophysiology of anxiety. Agents such as benzodiazepines, barbiturates, azapirones act as an allosteric modulator and direct agonist of GABA system, while certain anticonvulsant (valproate, gabapentin, pregabalin, and vigabatrin) increase brain GABA level by targeting metabolic pathway (Bandelow et al., 2012).

Sleep plays an important role in the regulation of central nervous system and body physiological parameters. However, the disruption in sleep leads to dysregulation of neurotransmitters. Glutamate and GABA are primarily involved in the pathophysiology of insomnia. Different pharmacological agents like benzodiazepine hypnotics and zolpidem, monoamine oxidase inhibitors, antihistamines, barbiturates are commercially available and proved to be clinically effective for the treatment of insomnia (Meyerhoff et al., 2014).

In spite of clinical significance of anxiolytic and hypnotic drugs, the major complications occur with these agents are their susceptibility to adverse effects and dependency. These considerations provide evidence for the development of new agents with less adverse effects (Predictable SEAU, 2006). In the search for a novel drug product for the treatment of psychiatric illness, large number of medicinal plants such as Areca catechu (Dar 
and Khatoon, 1997), Capsicum annuum (Jawad et al., 2017), Crocus sativum (Hosseinzadeh and Noraei, 2009), Hypericum perforatum (Kumar et al., 2000), Melissa officinalis (Akhondzadeh et al., 2003), Morus alba (Yadav et al., 2008), Nigella sativa (Raza et al., 2007), and Ziziphus spina-christi (Setorki, 2016) have been investigated for their therapeutic potential in variety of animal models.

Cocculus laurifolius (also known as laurel leaf snail tree) is an evergreen shrub or small tree of 1-2 $\mathrm{m}$ tall, belongs to the family Menispermaceae. The phytochemical analysis of leaves extract confirms the presence of phenolic compounds, flavanoids and tannins, responsible to produce antimicrobial and anti-oxidant activity. It has been established that water and ethanolic extracts of C. laurifolius possess selective biocide activity against several microorganisms (Ajaib et al., 2017). The ethanolic extract of leaves leads to the isolation of quarternary bases of the plant cocculidine and cocculine that exhibit hypotensive activity in dogs, cats and rabbits. While the quaternary apoporphine bases O-methylisocorydine, isocorydine and boldine methochlorides possess considerable ganglion blocking activity on sympathetic and parasympathetic ganglia (Bhakuni, 1984). These apoporphines bases act as a neuronal nicotinic acetylcholine receptor blocker (Iturriaga-Vásquez et al., 2007). The major alkaloids of C. laurifolius, isocorydine methochloride has been found to have neuromuscular blocking activity (Mukherjee et al., 1984). During the search of secondary metabolites from the ethanolic extract of C. laurifolius leaves, tetradrine (benzylisoquinoline alkaloid) was isolated, which is believed to possess the central nervous system effects and also exerts antidepressant effects in animal model (Bhakuni et al., 1980).

However, previously no such study has been reported on the anxiolytic and hypnotic activity of C. laurifolius. Hence, based on the evidence of possible central nervous system activity of plant leaves and its alkaloids, we have carried out the effect of ethanolic extract of $C$. laurifolius leaf for potential anxiolytic and hypnotic effects.

\section{Materials and Methods}

\section{Collection of plant material}

The fresh leaves of $C$. laurifolius were collected from the Botanic Garden GC University, Lahore in the month of October 2017, and was identified by Dr. Zaheer-uddin Khan, Herbarium Department of Botany, GCU Lahore with voucher specimen No. GCU-Herb-Bot 2997, for further reference. For the extraction of C. laurifolius, leaves were dried under shade for 15 days.

\section{Preparation of ethanolic extract}

After drying, the leaves were grounded and macerated in ethanol $(98 \% \mathrm{w} / \mathrm{v})$ for 7 days. The solvent was filtered out through the filter paper to remove all debris. The extract was concentrated by the help of rotary evaporator. The concentrated extract of $14.8 \mathrm{~g}$ was obtained. This extract was stored at $4^{\circ} \mathrm{C}$ in an airtight container.

\section{Chemicals}

Ethanol was purchased from BDH Laboratory (England); sodium chloride was procured from Sigma Chemical Company (USA). All other reagents and drugs used in the study are of pharmaceutical standards.

\section{Acute toxicity testing}

The mice were divided into 5 groups: control, 5, 50, 300 $\mathrm{mg}$ and $200 \mathrm{mg} / \mathrm{kg}$ (each group contained three mice), where the limit test dose used for the study was 2,000 $\mathrm{mg} / \mathrm{kg}$. Food was restricted for mice with free excess to water, a night before performing the test. All mice were weighed prior to dose administration. Doses were prepared by dissolving the extract in distilled water according to $1 \mathrm{~mL} / 100 \mathrm{~g}$ body weight of each mouse. Control group was kept on normal saline. All doses were administered via oral intubation. After drug administration, mice were observed for 24 hours for any mortality and toxic symptoms with special observation during initial 4 hours.

\section{Animals}

Swiss-albino NMRI, male mice weight (20-30 g) were procured and kept in the Animal house of Hafiz Muhammad Ilyas Research lab (HMI), Hamdard University. The animals were housed under a controlled environment at $50-60 \%$ humidity, $22-28^{\circ} \mathrm{C}$ temperature, and 12 hours light and dark cycle in plexiglas cages, with proper food and water supply. Mice were kept in a laboratory environment for adaptation, an hour before conducting tests. All tests were performed between 9 am to $4 \mathrm{pm}$, in a clean and noise free area.

\section{Drug administration}

Experimental mice were randomly divided into eight groups, each group containing $(n=7)$ animals. Two groups were served as control ( $0.9 \%$ normal saline), four groups were treated with the extract of $C$. laurifolius (200 and $400 \mathrm{mg} / \mathrm{kg}$ ). Diazepam (1 mg/kg) was used as a reference for both anxiolytic and hypnotic activity. The extract was dissolved in $1 \mathrm{~mL}$ distilled water to obtain the final concentration. All respective groups were administered orally via oral intubation, between 8 am to 10 am once daily for 30 days. Behavioral tests were conducted at day $1,7,15$ and 30 .

\section{Elevated-plus maze test}

The elevated-plus maze model consists of cross-shaped 
platform consisting of two open and two closed arms, $50-70 \mathrm{~cm}$ above the ground. Each animal was placed in the middle of the apparatus facing towards the close arm and allowed to freely explore the environment for $5 \mathrm{~min}$. The time spent in the open/close arm, percentage time spent in each arm (open/close), rearing and the total number of entries were recorded on day 1 , 7, 15 and 30 (Lister, 1987).

\section{Light-dark box test}

The light-dark apparatus consisted of a perspex test box. The box is divided into two compartments, one 27 $\times 27 \times 27 \mathrm{~cm}$ high transparent compartment, illuminated by $60-\mathrm{W}$ incandescent bulb while the other black opaque compartment of $27 \times 18 \times 27 \mathrm{~cm}$ high. Both light and dark compartments were connected by a small opening (7 $\times 7 \mathrm{~cm}$ high) (Chaouloff et al., 1997). The procedure was performed in a noise-free dark room. Mice were kept in the room an hour before performing the procedure (Hascoë and Bourin, 1998). Each mouse was placed at the center of the light compartment facing towards the opening to observe the behavior activity for $5 \mathrm{~min}$. The following behavioral parameters were observed: Time spent in each compartment (light/ dark), the number of transition in each compartment (light/dark), rearing and the total number of transition in each compartment. All parameters were recorded on day $1,7,15$ and 30 .

\section{Hole-board paradigm}

The apparatus was a plexiglass box of $40 \times 40 \times 30 \mathrm{~cm}$, with four holes equally spaced at $3 \mathrm{~cm}$ diameter on the

\section{Box 1: Open Field Test}

\section{Principle}

Open-field is used to measure locomotion, exploration and anxiety activities simultaneous. The number of line crosses and the frequency of rearing (the mice stood on their hind legs in the maze) are usually used as measures of locomotor activity. The number of central square entries and the duration of time spent in the central square are measures of exploratory behavior and anxiety.

\section{Requirements}

Digital camera (Canon A 4000 IS); Red lamp (60-Watt); Mouse; Rectangular arena; Transparent floor

\section{Procedure}

Step 1: The open-field is a rectangular arena of opaque acrylic walls of $37 \mathrm{~cm}$ in height and transparent floor $(80 \times 80 \times 15$ $\mathrm{cm})$

Step 2: The bottom of the arena is divided into 25 equal squares with dimensions of $16 \times 16 \mathrm{~cm}$

Step 3: The apparatus was lightened with indirect light and trial was conducted in a noise free room

Step 4: Each mouse was placed in the center of arena and the number of square crossed with four paws was recorded for 5 floor. The experiment was performed in a clean and noise-free area. Mice were divided into four groups stated previously. Each mouse was placed in the center of the apparatus and allowed to explore for $5 \mathrm{~min}$. The total number of head dips, rearing and latency to first head dip were observed.

\section{Sodium-pentobarbital-induced hypnosis}

In sodium pentobarbital-induced hypnosis, sleeping time and the onset of sleep were observed by change in the time of drug administration and time of loss of righting reflex, while the duration of sleep was represented by time to recover from righting reflex (Nugroho et al., 2012). On the day of test session, mice of respective groups were administered with normal saline $(10 \mathrm{~mL} / \mathrm{kg})$, diazepam, $1 \mathrm{mg} / \mathrm{kg}$ and ethanolic extract of C. laurifolius leaf (200 and $400 \mathrm{mg} / \mathrm{kg}$ ) via oral intubation. After $30 \mathrm{~min}$ of administration, mice were injected with sodium pentobarbital $40 \mathrm{mg} / \mathrm{kg}$ intraperitoneally (Mujumdar et al., 2000) and placed in separate cages. The onset of sleep (loss of righting reflex) and the duration of sleep were the observed parameters (Yemitan et al., 2001). Test sessions were conducted on day $1,7,15$ and 30 of treatment.

\section{Statistical analysis}

Data entry and analysis were performed using the Statistical Package for the Social Sciences (SPSS) version 20 . All results were presented as mean \pm SEM. One-way ANOVA and post-hoc Tukey were used for analysis. A probability value of $<0.05$ was considered as significant between the control and treated groups.

$\min$

Step 5: The observed parameters were the number of square crossed (peripheral and central squares) and total number of rearing

\section{Notes}

1. Walls may be opaque or clear. The clear walls are preferred for measurement of anxiety, while opaque walls for novel object recognition

2. Walls are easily detachable for easy cleaning

3. Grid floor insert available for video tracking

4. A high frequency of line crosses and rearing indicates increased locomotion and exploration and/or a lower level of anxiety

5. A high frequency/duration of central square entries/ duration of time spent indicates high exploratory behavior and low anxiety levels

6. Repeated exposure to the open field apparatus results in time-dependent changes in behavior

\section{References}

Archer, 1973; Walsh and Cummins, 1976; Tatem et al., 2014 (https:/ / bit.ly/2U283fY) 


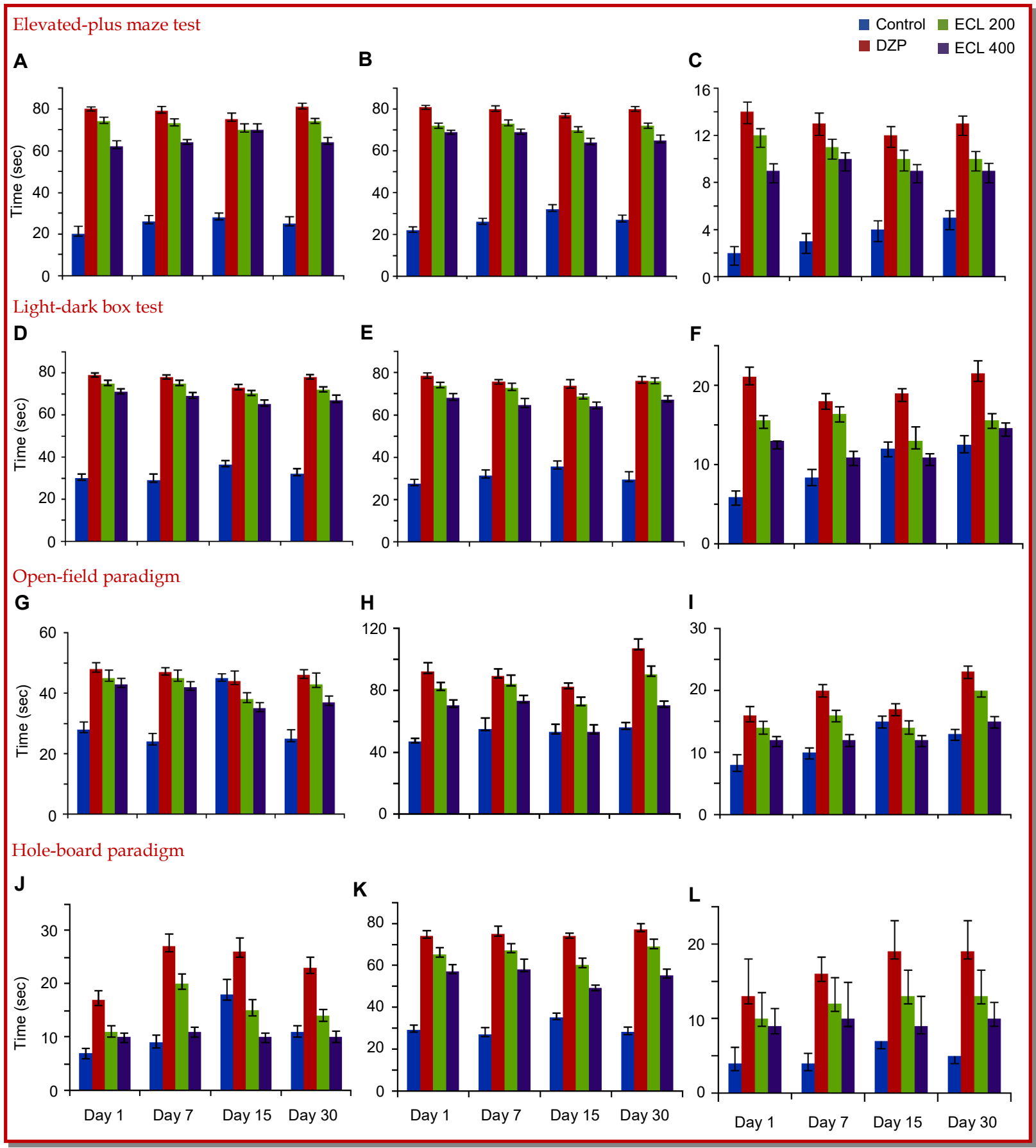

Figure 1: Effect of Cocculus laurifolius extract on A) percentage entries in open arm, B) percentage time spent in open arm and C) total number of rearing in elevated-plus maze test; Effect of Cocculus laurifolius extract on D) percentage number of entries, E) percentage time spent and F) total number of rearing in light area in light-dark box test; Effect of Cocculus laurifolius extract on G) number of center square crossed, $(\mathrm{H})$ number of peripheral square crossed and I) number of total number of rearing in open-field paradigm; Effect of Cocculus laurifolius extract on J) latency to first head dip, K) number of head dips and L) total number of rearing in hole-board paradigm; Data expressed as mean \pm SEM; $n=7$

\section{Results}

\section{Acute toxicity test}

There are no toxic symptoms and signs of mortality were observed after a single oral dose of 5, 50, 300 and $2,000 \mathrm{mg} / \mathrm{kg}$ of extract. The behavioral patterns of mice were observed for initial 4 hours, followed by 24 hours after administration in the control and treated groups. The treated groups did not show any significant change from the control in behavior patterns, skin and eye coloration, body temperature, food intake and no sign of mortality were observed. All mice showed minimal 
Table I

Effect of Cocculus laurifolius extract on latency time and duration of sleep in sodium-pentobarbital induced hypnosis

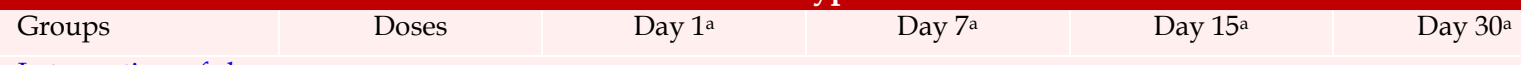

Latency time of sleep

Normal saline

$10 \mathrm{~mL} / \mathrm{kg}$

$7.3 \pm 0.3$

$8.1 \pm 0.6$

$9.9 \pm 0.5$

$9.7 \pm 0.5$

DZP

$1 \mathrm{mg} / \mathrm{kg}$

$4.6 \pm 0.2 \mathrm{c}$

$5.3 \pm 0.4 \mathrm{c}$

$4.9 \pm 0.4 \mathrm{c}$

$5 \pm 0.3 \mathrm{c}$

ECL I

$200 \mathrm{mg} / \mathrm{kg}$

$7.9 \pm 0.4$

$8.4 \pm 0.4$

$10.2 \pm 0.6$

$9.9 \pm 0.8$

ECL II

$400 \mathrm{mg} / \mathrm{kg}$

$6.3 \pm 0.5$

$6.1 \pm 0.4^{\mathrm{b}}$

$6 \pm 0.7 \mathrm{c}$

$6.1 \pm 0.6^{c}$

Duration of sleep

Normal saline

$10 \mathrm{~mL} / \mathrm{kg}$

$28.2 \pm 0.4$

$27.5 \pm 0.9$

$1 \mathrm{mg} / \mathrm{kg}$

$42.7 \pm 0.7 \mathrm{c}$

$42.9 \pm 1.1^{c}$

$24.2 \pm 0.8$

$26 \pm 0.5$

DZP

$200 \mathrm{mg} / \mathrm{kg}$

$28.1 \pm 0.5$

$28.1 \pm 0.5$

$41.4 \pm 1.2^{c}$

$44.4 \pm 1.4 \mathrm{c}$

ECL II

$400 \mathrm{mg} / \mathrm{kg}$

$34 \pm 1 \mathrm{c}$

$33.7 \pm 1^{c}$

$26 \pm 0.4$

$26 \pm 0.5$

$34.1 \pm 0.5^{c}$

$32.2 \pm 1.1^{c}$

Data expressed as \pm SEM; $n=7$; ${ }^{\mathrm{a}}<0.05 ;{ }^{\mathrm{b}} \mathrm{p}<0.01 ; \mathrm{c} p<0.001$ when compared with control groups

increment in body weight without any significant differ -ence between the control and treated groups. The maximum dose of $2,000 \mathrm{mg} / \mathrm{kg}$ did not show any considerable behavioral changes, except, drowsiness and sedation but these effects were diminished later. To further ameliorate the dose level for pharmacological study $1 / 10$ th i.e. $200 \mathrm{mg} / \mathrm{kg}$ and $1 / 5$ th i.e. $400 \mathrm{mg} / \mathrm{kg}$ of the (maximum dose 2,000 mg/ kg) was selected according to OECD guideline 423 .

\section{Elevated-plus maze test}

Effect of oral administration of ethanolic extract of $C$. laurifolius leaves and diazepam at day 1, 7, 15 and 30 in the elevated-plus maze were shown (Figure 1A-C). After day 1 treatment with the extract at doses (200 and $400 \mathrm{mg}$ ) had the tendency to significantly increase the percentage number of entries in open arm, percentage number of time spent in open arm and the total number of rearing as compare to the control. However, after 30 days of treatment, the extract had significantly increased all parameters of elevated-plus maze except the total number of rearing, which had been slightly reduced at dose $200 \mathrm{mg}$. The reference anxiolytic drug diazepam at $1 \mathrm{mg} / \mathrm{kg}$, significantly increased the percentage number of entries in open arm, percentage number of time spent in open arm and the total number of rearing in elevated-plus maze model as compared to the control at day 1, 7, 15 and 30 .

\section{Light/dark test}

The percentage number of entries and time spent in the light area along with the total number of rearing were significantly greater as compared to the control, from day 1 to 30 days of treatment with extract (200 and 400 $\mathrm{mg} / \mathrm{kg}$ ). In diazepam $1 \mathrm{mg} / \mathrm{kg}$, all parameters were relatively increased in the same fashion as that of the extract after 1 to 30 days treatment as compared to the control (Figure 1D-F).

\section{Open field test}

The number of center squares crossed had been significantly increased with diazepam $1 \mathrm{mg} / \mathrm{kg}$. Similar effects were observed by ethanolic extract of C. laurifolius leaves 200 and $400 \mathrm{mg} / \mathrm{kg}$ comparable to the control (Figure 1G-I). Meanwhile, the number of peripheral squares crossed and the total number of rearing were considerably augmented by extract at 200 and $400 \mathrm{mg} / \mathrm{kg}$ on day 1, 7, 15 and 30 of test sessions.

\section{Hole board test}

Latency to first head dip significantly reduced by ethanolic extract of C. laurifolius leaves 200 and $400 \mathrm{mg} /$ $\mathrm{kg}$ at $1,7,15$ and 30 th day test session. Similarly, the total number of head dips and rearing showed considerable escalation in comparison to the control. Similar results were observed with diazepam $1 \mathrm{mg} / \mathrm{kg}$ (Figure $1 \mathrm{~J}-\mathrm{L})$.

\section{Hypnotic activity}

Ethanolic extract of C. laurifolius leaves at dose $200 \mathrm{mg} /$ $\mathrm{kg}$ failed to produce a significant increase in the latency time to sleep, while the duration of sleep was also decreased in comparison to the control. While at dose $400 \mathrm{mg} / \mathrm{kg}$, a significant decrease in the latency to sleep and increase in the duration of sleep were observed in comparison to the control. Results obtained from the extract at dose $400 \mathrm{mg} / \mathrm{kg}$ were comparable to diazepam $1 \mathrm{mg} / \mathrm{kg}$, to produce hypnotic activity (Table I).

\section{Discussion}

In the present study, the ethanolic extract of $C$. laurifolius leaves showed no sign of toxicity and mortality. The behavioral changes were observed after a single oral dose of the extract. However, sedation and 
drowsiness were observed at a higher dose but no considerable change in body weight was observed. Generally, the significant change in the body weight is the indication of adverse effect from drug and chemical (Auletta, 1995). Furthermore, no significant change in the body weight and temperature were reported after administration, which postulated that the acute oral extract up to dose $2,000 \mathrm{mg} / \mathrm{kg}$ is safe (Adeneye et al., 2006). The present study also provides evidence for the beneficial effect of extract in anxiety and insomnia. The anxiolytic screening test of ethanolic extract of $C$. laurifolius leaves was conducted by exposing mice to a dilemma, whether to explore the new environment or to avoid it due to fear and potential danger (Bourin and Hascoët, 2015). For this purpose, well-reported animal models like the elevated plus maze, light/dark, open field and hole board tests are employed, which have prescient validity of consistent results in standard anxiolytic drugs (Belzung and Griebel, 2001).

In the present study, the ethanolic extract of $C$. laurifolius leaves (200 and $400 \mathrm{mg} / \mathrm{kg}$ ) produce a significant increase in the number of entries, time spent in open arm and rearing after 1 to 30 days of treatment. While similar results were seen after 30 days of treatment with a slight deviation of results at day 7 and 15. These results were comparable with diazepam (1 $\mathrm{mg} / \mathrm{kg}$ ). According to the previous published studies, the number of entries and time spent in open arm were sensitive to agents that act via GABA-A (gamma amino butyric acid receptor A) receptor complex, while diazepam is among the benzodiazepines that exert anxiolytic properties by directly targeting the GABA-A receptor (Nutt and Malizia, 2001).

Anxiolytic activity of ethanolic extract of C. laurifolius leaves (200 and $400 \mathrm{mg} / \mathrm{kg}$ ) was further evaluated by another animal model light-dark test. In the light-dark test, treated mice showed a significant increase in the number of entries and the time spent in light area at day 1 to 30 treatment as compared to control, which indicates the exploratory behavior of the animal, similar to Artocarpus lacucha leaves (Hossain et al., 2010). Rearing was also significantly increased. On the other hand, increase in the number of center squares crossed was observed in the open field test that indicates the decrease in anxiety and contributed as a measure of central exploration. While escalation in peripheral squares crossed and the number of rearing explains the exploratory activity of animal with the reduction in anxiety (Prut and Belzung, 2003). Similar outcomes were observed by extract at dose 200 and $400 \mathrm{mg} / \mathrm{kg}$ at day 1, 7, 15 and 30 test session.

In addition to this, a significant reduction in latency to first head dip, with augmentation in head dipping behavior and rearing by ethanolic extract leaves of $C$. laurifolius leaves at dose 200 and $400 \mathrm{mg} / \mathrm{kg}$. The increase in the number of head dips and rearing narrate the release of anxiety and anxiolytic effect of drug substance (Takeda et al., 1998).

The result from the above tests reveals that ethanolic extract of C. laurifolius leaves might have possessed potential anxiolytic activity at both doses (200 and 400 $\mathrm{mg} / \mathrm{kg}$ ), in which $200 \mathrm{mg} / \mathrm{kg}$, is the more potent anxiolytic dose. The mechanism of anxiolytic activity of the extract might be due to the presence of flavonoids, since flavonoids exerts their activity through GABA receptors. Previously many traditional plants like Morus alba. leaves (Yadav et al., 2008), Cissus sicyoides (Almeida et al., 2009), Cocculus hirsutus (Marya et al., 2012) and Hibiscus rosa sinensis (Begum and Younus, 2018) have been reported for their anxiolytic effect due to affinity of flavonoids for benzodiazepine receptors (Jäger and Saaby, 2011). Meanwhile, there might be a possible involvement of serotonergic pathway in producing the anxiolytic effect, as serotonin has been primarily implicated in anxiety-like behavior in rodents (Sfinchez et al., 1993). Plants like Citrus aurantium (Costa et al., 2013), Nigella sativa (Perveen et al, 2009), Cinnamomum cassia (Yu et al., 2007) are proved to produce anxiolytic effect via acting on the serotonin pathway. Moreover, the contributing alkaloids of C. laurifolius, aporphine and benzylisoquinoline have also been reported to produce anxiolytic activity via acting on dopaminergic (Yan et al., 2015), as dopamine receptors play an important role in mediating anxiolytic activity (Zarrindast and Khakpai, 2015). In addition to this, plants like Ficus carica (Bhanushali et al., 2014), Nymphaea lotus (Fajemiroye et al., 2018) and Asparagus racemosus (Singh et al., 2009) have been reported to produce anxiolytic effect by acting on noradrenergic pathway. So, it can be assumed that the anxiolytic effect produce by $C$. laurifolius leaves might be exhibited due to its possible involvement with noradrenergic pathway, as noradrenergic receptors play a significant role in anxiety (Massé et al, 2006). However, further studies are needed to justify this assumption as well as to identify the specific phytochemical constituent and along with endogenous mediator involved responsible to produce anxiolytic activity.

The hypnotic activity of ethanolic extract leaves of $C$. laurifolius leaves was observed by sodium-pentobarbital-induced hypnosis in comparison with diazepam. The extract did not exhibit any hypnotic activity at dose $200 \mathrm{mg} / \mathrm{kg}$, however, dose $400 \mathrm{mg} / \mathrm{kg}$ produce minimal hypnotic activity with inhibition in the onset of sleep and prolonged duration of sleep in comparison with control. The hypnotic effect of the extract at dose $400 \mathrm{mg} / \mathrm{kg}$ increases with the duration of treatment at day 30, while dose $200 \mathrm{mg} / \mathrm{kg}$ does not show any alterations. This indicates that extract might have possessed hypnotic activity at higher doses. It has been reported that prolongation of sleep may be due to hepatic enzyme metabolism and the effect of 
pentobarbital on the central nervous system involves activation of inhibitory GABAergic system (AguirreHernández et al., 2007). The prolongation in the duration of sleep by the extract might be due to the involvement of GABAergic system.

According to Bhakhuni et al., (1980) leaves of C. laurifolius contains tetrandrine, this compound has been previously reported to increase the hypnotic effect induced by pentobarbital via acting on serotonergic pathway, like ferulic acid (Zhao et al., 2004; Tu et al., 2012). Although, some studies also supported the involvement of saponins in producing hypnotic activity of plant extract (Jiang et.al, 2007; Rakhshandah and Hosseini, 2006; Yao et al., 2010). While tannins have also been suggested to produce hypnotic activity by nonspecific central nervous system depression via acting on GABAergic pathway (Takahashi et al., 1986). However, further investigations are needed to support these assumptions.

The ethanolic extract of $C$. laurifolius leaves which were previously reported for its antimicrobial, anti-oxidant, neuromuscular and ganglionic blocking activity, has been evaluated for anxiolytic and hypnotic activity. In the light of pharmacological activity of behavioral animal models in mice on acute and repeated treatment, and statistical significance of the results, it has been evaluated that the ethanolic extract of C. laurifolius leaves might have potential anxiolytic activity and minimal hypnotic activity at higher dose of $400 \mathrm{mg} / \mathrm{kg}$, while $200 \mathrm{mg} / \mathrm{kg}$ fails to produce hypnosis. Previously, different medicinally active plants; Capsicum annuum (Jawad et al., 2017), Citrus aurantium (Carvalho-Freita, 2002), citrus limon (Lopes Campêlo et al., 2011) and Magnolia dealbata (Martinez et al., 2006) have also been reported to possess anxiolytic and hypnotic activities on different doses. Furthermore, no signs of toxicity after 30 days of treatment with extract was observed, which reflects the safety profile of extract. These effects may be attributed due to the presence of rich content of flavonoids (Ajaib et al., 2017), alkaloids (erythrina and isocorydine methochloride), apoporphines and quarternary bases in ethanolic extract of C. laurifolius. However, there is a need for further investigation on the pharmacological activity of these active principals of the plant.

Furthermore, behavioral testing on different doses of ethanolic extract of C. laurifolius leaves is needed to enlighten the therapeutic significance of this plant in the treatment of anxiety and insomnia. Moreover, it is also important to study the involvement of neuronal pathway (GABAergic, serotogenic or dopaminergic pathways) by which ethanolic extract of C. laurifolius leaves produces anxiolytic and hypnotic effect.

\section{Conclusion}

The acute and repeated dosing of ethanolic extract of $C$. laurifolius leaves are effective in the treatment of anxiety and insomnia.

\section{Ethical Issue}

All the research protocol, procedures, euthanasia as well as ethical clearance were approved by the Board of Advanced Studies and Research, Hamdard University, Karachi (No. PSMP-16-039). The animals used in the study were handled as per specifications described in Helsinki Resolution 1964. The acute oral toxicity test was conducted according to Organization for Economic Co-operation and Development (OECD) guideline 423 on Swiss-albino NMRI male mice of (20 $-30 \mathrm{~g})$ (Class, 2001).

\section{Conflict of Interest}

The authors have no conflict of interest.

\section{Acknowledgement}

The authors are grateful to Hafiz Muhammad Ilyas Research lab, Hamdard University, for technical support and assistance.

\section{References}

Adeneye AO, Adeleke AT, Bello S. Preliminary toxicity and phytochemical studies of the stem bark aqueous extract of Musanga cecropioides in rats. J Ethnopharmacol. 2006; 105: 374-79.

Aguirre-Hernández E, Martínez AL, González-Trujano ME, Moreno J, Vibrans H, Soto-Hernández M. Pharmacological evaluation of the anxiolytic and sedative effects of Tilia americana L. var. mexicana in mice. J Ethnopharmacol. 2007; 109: $140-45$.

Ajaib M, Ashraf Z, Siddiqui MF. Cocculus laurifolius: A rich antimicrobial, anti-oxidant and phytochemical source. Pakistan J Bot. 2017; 49: 337-44.

Akhondzadeh S, Noroozian M, Mohammadi M, Ohadinia S, Jamshidi AH, Khani M. Melissa officinalis extract in the treatment of patients with mild to moderate Alzheimer's disease: A double blind, randomised, placebo controlled trial. J Neurol Neurosurg Psychiatry. 2003; 74: 863-66.

Almeida ERD, Rafael KRDO, Couto GBL, Ishigami ABM. Anxiolytic and anticonvulsant effects on mice of flavonoids, linalool, and $\alpha$-tocopherol presents in the extract of leaves of Cissus sicyoides L. (Vitaceae). Bio Med Res Int. 2009, 2009.

Archer J. Tests for emotionality in rats and mice: A review. Animal Behaviour, 1973.

Auletta CS. Acute, subchronic, and chronic toxicology. London, CRC Press, 1995. 
Bandelow B, Sher L, Bunevicius R, Hollander E, Kasper S, Zohar J, Möller HJ, WFSBP Task Force on Mental Disorders in Primary Care, WFSBP Task Force on Anxiety Disorders OCD and PTSD. Guidelines for the pharmacological treatment of anxiety disorders, obsessive-compulsive disorder and posttraumatic stress disorder in primary care. Int J Psychiatry Clin Pract. 2012; 16: 77-84.

Begum Z, Younus I. Hibiscus rosa sinensis mediate anxiolytic effect via modulation of ionotropic GABA-A receptors: Possible mechanism of action. Metab Brain Dis. 2018; 33: 82327.

Belzung C, Griebel G. Measuring normal and pathological anxiety-like behaviour in mice: A review. Behavioural Brain Res. 2001; 125: 141-49.

Bhakuni D. Alkaloids from Indian medicinal plants and their biosynthesis. Proceedings of the Indian Academy of Sciences -Chemical Sciences, Springer, 1984.

Bhakuni DS, Jain S, Singh AN. Biosynthesis of the bisbenzylisoquinoline alkaloid, tetrandrine. Phytochemistry 1980; 19: 2347-50.

Bhanushali MM, Makhija DT, Joshi YM. Central nervous system activity of an aqueous acetonic extract of Ficus carica L. in mice. J Ayurveda Integr Med. 2014: 5: 89.

Bourin M, Hascoët M. The mouse light/dark box test. Eur J Pharmacol. 2003; 463: 55-65.

Carvalho-Freitas MIR, Costa M. Anxiolytic and sedative effects of extracts and essential oil from Citrus aurantium L. Biol Pharm Bull. 2002; 25: 1629-33.

Chaouloff F, Durand M, Mormede P. Anxiety-and activityrelated effects of diazepam and chlordiazepoxide in the rat light/dark and dark/light tests. Behavioural Brain Res. 1997; 85: 27-35.

Class, A. O. T.-A. T. OECD guideline for testing of chemicals, 2001.

Costa CA, Cury TC, Cassettari BO, Takahira RK, Flório JC, Costa M. Citrus aurantium L. essential oil exhibits anxiolyticlike activity mediated by 5-HT 1A-receptors and reduces cholesterol after repeated oral treatment. BMC Complement Altern Med. 2013; 13: 42.

Dar A, Khatoon S. Antidepressant effects of ethanol extract of Areca catechu in rodents. Phytother Res. 1997; 11: 174-76.

Fajemiroye JO, Zjawiony Jordan K, Alves CE, Aderoju AA. Evaluation of anxiolytic and antidepressant-like activity of aqueous leaf extract of Nymphaea lotus Linn. in mice. Iranian J Pharm Res. 2018; 17: 613.

Hascoë TM, Bourin M. A new approach to the light/dark test procedure in mice. Pharmacol Biochem Behav. 1998; 60: 64553.

Hossain M, Hasan SR, Mukta M, Akter R, Mazumder MEH, Faruque A, Rana MS. Anxiogenic activity of methanol extracts of Artocarpus Lacucha Buch.-Ham. fruit parts and leaf in mice. Eur J Sci Res. 2010; 46: 592-603.

Hosseinzadeh H, Noraei NB. Anxiolytic and hypnotic effect of Crocus sativus aqueous extract and its constituents, crocin and safranal, in mice. Phytother Res. 2009; 23: 768-74.
Iturriaga-Vásquez P, Pérez EG, Slater EY, Bermudez I, Cassels BK. Aporphine metho salts as neuronal nicotinic acetylcholine receptor blockers. Bioorg Med Chem. 2007; 15: 336872 .

Jäger AK, Saaby L. Flavonoids and the CNS. Molecules 2011; 16: 1471-85.

Jawad M, Khan H, Pervez S, Bawazeer S, Abu-Izneid T, Saeed M, Kamal M. Pharmacological validation of the anxiolytic, muscle relaxant and sedative like activities of Capsicum annuum in animal model. Bangladesh J Pharmacol. 2017; 12: $439-47$.

Jiang JG, Huang XJ, Chen J, Lin QS. Comparison of the sedative and hypnotic effects of flavonoids, saponins, and polysaccharides extracted from semen Ziziphus jujube. Nat Prod Res. 2007; 21: 310-20.

Kumar V, Jaiswal AK, Singh PN, Bhattacharya SK. Anxiolytic activity of Indian Hypericum perforatum Linn: An experimental study. Anxiolytic activity of Indian Hypericum perforatum Linn: An experimental study. Indian J Exp Biol. 2000; 38: 3641.

Lister RG. The use of a plus-maze to measure anxiety in the mouse. Psychopharmacology 1987; 92: 180-85.

Lopes Campêlo LM, Gonçalves e Sá C, de Almeida AAC, Pereira da Costa J, Costa Marques TH, Mendes Feitosa C, Barros Saldanha G, Mendes de Freitas R. Sedative, anxiolytic and antidepressant activities of Citrus limon (Burn) essential oil in mice. Die Pharmazie. 2011; 66: 623-27.

Martinez AL, Dominguez F, Orozco S, Chavez M, Salgado H, Gonzalez M, González-Trujano ME. Neuropharmacological effects of an ethanol extract of the Magnolia dealbata Zucc. leaves in mice. J Ethnopharmacol. 2006; 106: 250-55.

Marya $\mathrm{BH}$, Bothara S. Evaluation of anxiolytic activity of methanolic and aqueous root extracts of Cocculus hirsutus. Int J Pharm Pharm Sci. 2012; 4: 186-87.

Massé F, Hascoët M, Dailly E, Bourin M. Effect of noradrenergic system on the anxiolytic-like effect of DOI (5HT2A/2C agonists) in the four-plate test. Psychopharmacology 2006: 183: 471-81.

Meyerhoff DJ, Mon A, Metzler T, Neylan TC. Cortical gammaaminobutyric acid and glutamate in posttraumatic stress disorder and their relationships to self-reported sleep quality. Sleep 2014; 37: 893-900.

Mujumdar A, Naik D, Waghole R, Kulkarni D, Kumbhojkar M. Pharmacological studies on Sterculia foetida leaves. Pharm Biol. 2000; 38: 13-17.

Mukherjee K, Patnaik G, Bhakuni D, Dhawan B. Mechanism of neuromuscular blocking action of isocorydine methochloride, a new quaternary alkaloid from Cocculus laurifolius DC. Indian J Exp Biol. 1984; 22: 54-56.

Nugroho A, Kim MH, Choi J, Baek NI, Park HJ. In vivo sedative and gastroprotective activities of Salvia plebeia extract and its composition of polyphenols. Arch Pharm Res. 2012; 35: 1403-11.

Nutt DJ, Malizia AL. New insights into the role of the GABA $A^{-}$ benzodiazepine receptor in psychiatric disorder. Bri J Psychiatry. 2001; 179: 390-96. 
Perveen T, Haider S, Kanwal S, Haleem DJ. Repeated administration of Nigella sativa decreases 5-HT turnover and produces anxiolytic effects in rats. Pakistan J Pharm Sci. 2009; 22: 139-44.

Predictable SEAU. Side effects of antidepressants: An overview. Cleveland Clin J Med. 2006; 73: 351.

Prut L, Belzung C. The open field as a paradigm to measure the effects of drugs on anxiety-like behaviors: A review. Eur J Pharmacol. 2003; 463: 3-33.

Rakhshandah H, Hosseini M. Potentiation of pentobarbital hypnosis by Rosa damascena in mice. Indian J Exper Biol. 2006; 44: 910-12.

Raza M, El-Hadiyah TM, Al-Shabanah O.A. Nigella sativa seed constituents and anxiety relief in experimental models. J Herbs Spices Med Plants. 2007; 12: 153-64.

Reynolds E. Brain and mind: A challenge for WHO. Lancet 2003; 9373: 1924-25.

Setorki M. Effect of hydro-alcoholic extract of Ziziphus spinachristi against scopolamine-induced anxiety in rats. Bangladesh J Pharmacol. 2016; 11: 421-27.

Singh GK, Garabadu D, Muruganandam AV, Joshi VK, Krishnamurthy S. Antidepressant activity of Asparagus racemosus in rodent models. Pharmacol Biochem Behav. 2009; 91: 28390.

Sfinchez C, Arnt J, Hyttel J, Moltzen EK. The role of serotonergic mechanisms in inhibition of isolation-induced aggression in male mice. Psychopharmacology 1993; 110: 53-59.

Takahashi RN, de Lima TC, Morato GS. Pharmacological actions of tannic acid; II. Evaluation of CNS activity in animals. Pharm Bull. 1986; 31: 2150.

Takeda H, Tsuji M, Matsumiya T. Changes in head-dipping behavior in the hole-board test reflect the anxiogenic and/or anxiolytic state in mice. Eur J Pharm. 1998; 350: 21-29.

Tatem KS, Quinn JL, Phadke A, Yu Q, Gordish-Dressman H, Nagaraju K. Behavioral and locomotor measurements using an open field activity monitoring system for skeletal muscle diseases. J Vis Exp. 2014; e51785.

Tu Y, Cheng SX, Sun HT, Ma TZ, Zhang S. Ferulic acid potentiates pentobarbital-induced sleep via the serotonergic system. Neurosci Lett. 2012; 525: 95-99.

Walsh RN, Cummins RA. The open-field test: A critical review. Psychol Bull. 1976; 83: 482-504.

Yadav AV, Kawale LA, Nade VS. Effect of Morus alba L. (mulberry) leaves on anxiety in mice. Indian J Pharmacol. 2008; 40: 32.

Yan MZ, Chang Q, Zhong Y, Xiao BX, Feng L, Cao FR, Pan RL, Zhang ZS, Liao YH, Liu XM. Lotus leaf alkaloid extract displays sedative-hypnotic and anxiolytic effects through GABAA receptor. J Agric Food Chem. 2015; 63: 9277-85.

Yao Y, Jia M, Wu JG, Zhang H, Sun LN, Chen WS, Rahman K. Anxiolytic and sedative-hypnotic activities of polygalasaponins from Polygala tenuifolia in mice. Pharm Biol. 2010: 48: 801 $-07$.

Yemitan O, Ajibade A, Adeyemi O. Anticonvulsant activity of Dalbergia saxatilis. Nigerian J Neurosci. 2001; 4: 33-40.

Yu HS, Lee SY, Jang CG. Involvement of 5-HT1A and GABAA receptors in the anxiolytic-like effects of Cinnamomum cassia in mice. Pharmacol Biochem Behav. 2007; 87: 164-70.

Zarrindast MR, Khakpai F. The modulatory role of dopamine in anxiety-like behavior. Arch Iranian Med. 2015; 18: 591-603.

Zhao X, Cui XY, Chen BQ, Chu QP, Yao HY, Ku BS, Zhang YH. Tetrandrine, a bisbenzylisoquinoline alkaloid from Chinese herb Radix, augmented the hypnotic effect of pentobarbital through serotonergic system. Eur J Pharmacol. 2004; 506: 101-05.

\footnotetext{
Author Info

Ishrat Younus (Principal contact)

I e-mail: ishratyounas@gmail.com
} 